\title{
Economic policy as a tool to eliminate the effects of the global economic crisis
}

\author{
Vendula Tesařová ${ }^{1, *}$ \\ ${ }^{1}$ University of West Bohemia, Faculty of Economics, Department of Economics and Quantitative \\ Methods, Univerzitní 22, 30614 Plzeň, Czech Republic
}

\begin{abstract}
.
Research background: The global economy has gone through two major crises since the beginning of the millennium. The first broke out in 2008 . The cause was the crisis in the financial markets in the United States. This crisis eventually spread around the world, causing many economies to decline. It remained not only in the financial markets, but also spilled over into other sectors of the affected economies. We are experiencing the second major crisis these days (2020). However, this crisis has a completely different origin. It is a crisis caused by a new type of viral disease.

The purpose of the article: Purpose is to compare the measures taken to mitigate the effects of the 2008 crisis with those used in 2020. The article is not just a simple list of individual measures, but a comparison of the time horizon in which it came and to whom it was targeted. The analyzed economy is the Czech Republic and its economic policy.

Methods: The article uses the method of analysis and statistical analysis, which is based on data from the CNB, the Ministry of Finance of the CR and the Czech Statistical Office. Data from the CVVM Public Opinion Research Center were used to illustrate the situation.

Findings \& Value added: Monetary and fiscal policy have relatively limited options in terms of the number of instruments they can use to combat the crisis. However, a difference can be observed in the response of economic policy makers to the 2008 and 2020 crises.
\end{abstract}

Keywords: monetary policy; fiscal policy; expansion; global economic crisis

JEL Classification: $E 62 ; E 12 ; E 58 ; E 65$

* Corresponding author: vendula.masatova@email.cz 


\section{Introduction}

A crisis or recession is a natural part of the economic cycle. The Bible already speaks of seven good years and seven skinny years. Since Keynes, governments have sought to eliminate downturns in the economic cycle as quickly as possible. They use various economic policy instruments to do so. Recently, the crisis has been so undesirable that governments and central banks are approaching it "healing" very soon and very vigorously.

The article will compare the approaches of the Czech National Bank and the Czech government to two different crises. The first originates in the US mortgage market, the second is the current crisis caused by the COVID-19 pandemic. In the first crisis, we were able to read certain signals from the market. The second was caused by external shock and the government's efforts to protect the health of the population, even at the cost of great economic losses.

At a time of any crisis, economic policy has a whole range of tools it can use to tackle it. Fiscal policy may change the settings of the built-in stabilizers or use individual discrete measures. As part of these measures, it may change tax rates, change the amount of transfer payments or government purchases. Monetary policy has basic interest rates, reserve requirements or monetary interventions. Sometimes markets are affected by the governor's very word. External trade policy and its tariffs and quotas or pension policy can also be used. The article will focus on fiscal and monetary policy.

\section{Financial crisis}

The mortgage crisis began in the United States in 2007. Respectively, this year the problems of the local mortgage market began to manifest themselves. From February 20, 2007, the mortgage market began to decline, which was subsequently supported several times. Signals appeared on the European market, for example, in August 2007, when the French investment bank BNP Paribas blocked withdrawals from two of its hedge funds. The official start of the crisis can be considered the full takeover of the semi-state mortgage agencies Fannie Mae and Freddie Mac by the US government. It happened on September 7, 2008. One of the highlights of the crisis was the collapse of the investment bank Lehman Brothers on September 15, 2008. The Federal Reserve announced that it would use the funds it last resorted to in the 1930s to solve the crisis. The banking sector was affected not only by the US system of central banks, but also by the US government. The assistance consisted of providing loans, ensuring protection from creditors, but also the entry of the state into selected financial institutions. Several large financial institutions went bankrupt in the United States. The crisis in the banking sector subsequently affected the stock markets and the corporate sector. The crisis has been so significant that its causes, consequences and how to prevent its recurrence are still being addressed by the professional public. [1 - 3]

Thanks to the purchase of so-called toxic securities, the crisis spilled over into European banks and their funds. Uncertainty about developments in the banking sector also affected consumer demand. The global crisis ended in the second half of 2009, when the US and European Union economies grew for the second consecutive quarter. [4]

This crisis was considered the worst since the 1930s. However, it lasted less than a year. (If we consider the above-mentioned date of September 7, 2008 as the beginning and the end of the resumption of growth of the US and EU economies in the second half of 2009 as its end.) 


\subsection{Development of the financial crisis in the Czech Republic}

From the point of view of the Czech economy, it was an imported crisis. One could actually say that the crisis in the Czech Republic was not financial, but economic. It did not originate in our territory. It arrived here with some delay. Back in 2008, the Czech economy was in positive numbers with excellent growth potential. If we look, for example, at the Czech National Bank's forecasts, we will see that on 7 February 2008 the CNB predicted GDP growth of $4.1 \%$ in 2008 and even $4.6 \%$ in 2009. [5]

In 2008, the unemployment rate in the Czech Republic was $4.4 \%$. The following year it was $6.7 \%$, in $20107.3 \%$. In the following years, the unemployment rate fell. Unemployment rose by 1.2 percentage points in total. However, in manufacturing it increased by 5.9 percentage points. [6]

The exchange rate also reacted to this global situation, weakening to $29.135 \mathrm{CZK} / \mathrm{EUR}$ at the beginning of the year. The process of weakening the koruna began on 21 July 2008, when, according to the CNB exchange rate list, one euro was available for CZK 22.97. [7]

\subsection{Fiscal policy instruments}

On February 16, 2009, the government of Mirek Topolánek approved the National AntiCrisis Plan. The document already reminds in its introduction that the current problem of the Czech economy is not a decline in domestic demand, but foreign demand. Therefore, the proposed measures do not primarily serve to stimulate domestic AD. Stimulating foreign demand is a very difficult, if not impossible, thing for a small open economy. According to Minister of Finance Miroslav Kalousek, fiscal policy at the time targeted the supply side of the economy. The demand side was not completely eliminated, but was not a priority. For example, the plan does not include an increase in transfer payments. Rather, it aims to support the maintenance of employment. The measures approved were as follows:

I. Reduction of the rate of insurance premiums for health insurance and state employment policy - paid by the employee by $6.5 \%$, paid by the employer by $1 \%$.

II. Reduction of the corporate income tax rate from $21 \%$ to $20 \%$ and subsequently in 2010 to $19 \%$. This measure was to leave 6.8 billion crowns in the hands of companies.

III. Increase of guarantees for small and medium-sized enterprises: provision of guarantees for operating and export loans in the total amount of CZK 8 billion. The guarantee was provided by the Czech-Moravian Guarantee and Development Bank.

IV. Support for entrepreneurs in agriculture by providing loans for small and mediumsized entrepreneurs in agriculture. The measure was implemented through the PGRLF (Support and Guarantee Forestry and Peasant Fund).

V. Strengthening the Rural Development Program.

VI. Investments in science and research beyond the approved draft state budget.

VII. Increasing investment in transport infrastructure.

VIII. Increase in salaries of state employees - this measure falls outside the whole concept of the rescue package.

IX. Voluntary return project. It consisted of paying travel to third-country nationals to their home country. On the other hand, the issuance of work visas to foreigners was suspended. The government wanted to prevent these people from getting into a difficult situation here after a possible loss of employment.

$\mathrm{X}$. Export support was designed in cooperation with the Czech Export Bank. Its share capital was increased and new products were designed to support exports to new territories.

XI. Adjustment of tax advances, the possibility of repayment calendars. 
XII. Adjustment of the expenditure side of the budget in the area of financing state institutions. [8]

\subsection{Monetary policy instruments}

Banks operating in the Czech Republic were not affected by the financial crisis. Their portfolio did not contain toxic assets. Nevertheless, the Czech National Bank has implemented some monetary policy measures to mitigate the effects of the economic crisis on the Czech economy.

One of the measures was a change in key interest rates. The first reduction in the discount rate took place on 8 August 2008 , by a quarter of a percentage point to $2.5 \%$. The discount rate gradually decreased to the level of $0.25 \%$ (August 7,2009 ). It remained at this level until 1 October 2012, when it fell further. [9]

The development of other basic interest rates is also shown in Table 1:

Tab. 1: Development of basic interest rates

\begin{tabular}{|c|c|c|c|}
\hline date of change & discount rate & lombard rate & repo rate \\
\hline Feb.08.2008 & 2,75 & 4,75 & 3,75 \\
\hline Aug.08.2008 & 2,50 & 4,50 & 3,50 \\
\hline Nov.07.2008 & 1,75 & 3,75 & 2,75 \\
\hline Dec.18.2008 & 1,25 & 3,25 & 2,25 \\
\hline Feb.06.2009 & 0,75 & 2,75 & 1,75 \\
\hline May.11.2009 & 0,50 & 2,50 & 1,50 \\
\hline Aug.07.2009 & 0,25 & 2,25 & 1,25 \\
\hline Dec.17.2009 & 0,25 & 2,25 & 1,00 \\
\hline May.07.2010 & 0,25 & 2,25 & 0,75 \\
\hline
\end{tabular}

Source: [9]

\section{Covid crisis}

This crisis is completely different from the previous one. It was caused by the onset of a new viral disease. The virus, later known as SARS-COV-19, began to spread worldwide from China. While the crisis in the financial markets has shown the interconnectedness of the financial sector, this crisis has shown the interconnectedness of the world in terms of population displacement. Thanks to tourism and business trips, the virus spread very quickly around the world. [10] Concerned about the development of an unknown disease, governments have curtailed economic activity in individual states. The damage was then addressed by a massive expansionary economic policy. [11] The approach of individual states differed quite a bit. Some governments responded relatively quickly, others initially seemed to underestimate the risks. E.g. The British Prime Minister Boris Johnson has long rejected any measures. [12] South Korea initially took a much more responsible approach. However, even this did not go without a fiscal impulse. [13] Sweden has taken a completely different approach to economic restrictions. [14] But even there, the help of economic policy came in. The European Union as a whole seems to have failed at this time. She left it to the individual sucks to deal with the crisis. It also did not set uniform rules for restrictions, risks, population testing. No recommendation was issued. [15] 


\subsection{Development of a pandemic in the Czech Republic}

At the beginning of 2020, the Czech economy showed very good numbers, as it did before the onset of the crisis in 2009. Unemployment in 2019 was one of the lowest in the EU. It reached only two percent. [16] The Czech labor market has been exhausted. People registered at labor offices did not meet the requirements of employers, and although the number of job vacancies exceeded the number of job seekers by tens of thousands, people at labor offices were no longer significantly reduced. Even during 2020, it did not increase sharply. In addition, with the onset of autumn, companies began to publish new requirements for positions in logistics associated with Christmas shopping. These posts would normally be filled by workers from abroad. Labor mobility is still very limited due to COVID-19.

Gross domestic product in 2019 grew at a rate of $2.3 \%$. Since 2017, its growth rate has been declining. [17] The crisis as such was in sight, but it was not on the agenda the following year. According to estimates, gross domestic product in the Czech Republic fell by $10.7 \%$ in the first half of the year compared to the first half of 2019 .

The exchange rate reacted to the government's restrictive measures. The koruna was the weakest at the moment when the borders for daily commuters were closed for a short time. On March 24, 2020, one euro cost CZK 27.81. [7]

\subsection{Fiscal policy instruments}

The government of the Czech Republic reacted to the new situation relatively quickly. It did not wait weeks or months, but restrictive measures were introduced practically from the day. The first case of COVID-19 was confirmed in our territory on March 1, 2020. On March 2, flights to Italy and South Korea were banned. The economy shut down on March 14. However, the first fiscal policy measure came five days earlier.

With a slight lag of time, we can summarize the government's measures from the first half of 2020 relatively clearly, although in the period from March to June, the government came up with new proposals relatively chaotically and unsystematically. An abbreviated list of government measures to support the economy could look like this:

I. Tax relief. It was a whole package that did not change the given rates, but, for example, postponed the date of the tax return for 2019 until 31 July 2020 without any sanctions. In addition, VAT on donated medical supplies was waived, advance payments were deferred, electronic records of sales (EET) were suspended or all sanctions resulting from late payment of taxes were waived.

II. Support for self-employed persons. In addition to the normal situation, self-employed persons have been given the opportunity to draw so-called nursing allowances for children under 13 years of age. First in the amount of 424 crowns per day, from May 1, the contribution was increased to 500 crowns per day. This support ended on 30 June 2020 at the end of the school year. In the months of March to August, entrepreneurs were forgiven for payments of health and social insurance. Entrepreneurs were also paid a compensatory bonus of 25,000 crowns under clearly defined conditions. No matter how high their sales have been in the past. It was a matter of a reduction in earning activity in the spring of 2020 due to the occurrence of COVID-19.

III. Compensation bonus for DPP and DPC who participated in health insurance as an employee. The bonus was set at 350 crowns per day, a maximum of 31,500 crowns per person.

IV. Support for maintaining employment.

This support includes, for example, the COVID loan program. The volume of funds contained in it proved to be insufficient, and so the COVID II and COVID III program was 
subsequently approved with a total volume of guarantees of 150 billion crowns. Guarantees are realized through the Czech-Moravian Guarantee and Development Bank.

Furthermore, the COVID 19 Technology program was approved for the purchase of technologies and equipment for limiting the spread of COVID 19. The maximum support for one subject was 20 million crowns, 300 million crowns were earmarked. The main goal was to maintain the operation of companies and limit the spread of the virus in companies whose operation was not restricted by the state.

The Antivirus program compensated companies for a significant part of labor costs. It was divided into three categories: Antivirus A, Antivirus B and Antivirus C. The classification into individual types depended on the reason for the restriction of the company's activities.

For large companies, the COVID + program was approved for companies with more than 250 employees. The program consisted of a system of guarantees from the Export and Guarantee Insurance Company. Later, carriers and companies doing business in tourism and companies providing infrastructure construction could apply for the program.

Special programs have been approved for tenants of non-residential projects, for entrepreneurs in tourism, for entrepreneurs in culture, for sports organizations, for zoos and for accommodation facilities.

V. Support for farmers, foresters and food producers. There has been an increase in funding for the rural development program. There was an effort by the government to help farmers mediate the search for employees. The field lacked foreign workers who regularly came for the seasonal collection of fruit and vegetables. (This proved to be a big problem in virtually every country in the world - workers either could not come or could not leave their homes.) [18]

VI. The measure for employees consisted only in extending the nursing allowance for the entire period of school closure, increasing it to $80 \%$ of the reduced earnings base. Parents up to the age of 13 could receive this benefit. Under normal circumstances, this limit was 10 years. [19]

Further measures followed in the second half of 2020. The Antivirus program has been replaced by a course work, extraordinary bonuses have been proposed for old-age and disabled pensioners. The Ministry of Labor and Social Affairs pointed out that financial assistance should also be provided to single people. Additional support for carriers and hoteliers is being prepared.

Not only the government has taken action to eliminate the covid shock, but many regions or specific cities have also been actively involved. [20]

In addition to these measures, a home office was also recommended. The aim was to reduce people's contacts in the offices. It discusses its suitability for various professions [21].

\subsection{Monetary policy instruments}

Even during this crisis, the central bank supported the availability of capital. It again lowered its key interest rates. [9]

Compared to the previous crisis, it has eased the conditions for providing mortgages. Mortgage regulation began in 2015 . The amount of the mortgage provided was gradually reduced to $80 \%$ of the value of the mortgaged property. The amount of the installment in relation to the total income of the mortgage interested in the interest was also limited, and the ratio of the amount of the applicant's total debt in relation to his net annual income was also monitored. From the first of April 2020, the limit of $80 \%$ was increased to $90 \%$. The ratio of total debt to net annual income ceased to be monitored (originally eight times). The amount of installments can now be $50 \%$ of net monthly income (originally $45 \%$ ). The 
measure was intended to help alleviate the slowdown in the mortgage market caused, for example, by pessimistic consumer prospects. [22]

\section{Conclusion}

Both crises, the one from 2009 and the current one from 2020, arose outside the territory of the Czech Republic. The causes were diametrically opposed. In the first case, it was the irresponsible behavior of American banks, which subsequently triggered first the global financial, then the economic crisis. The second case was a new viral disease originating in China, which paralyzed many world economies through government restrictive measures.

The aim of this article was to compare the measures taken by the central bank and the government in 2009 and in 2020. In 2009, the central authorities could prepare for a possible negative economic shock. The crisis began in the United States two years earlier and it took some time before it spilled over into the real sector in the Czech Republic. In 2020, the government itself cut off economic activity overnight. No predictive models could assume this - the extent and duration of the economic shutdown.

The available data show that the central bank proceeded similarly in the area of interest rates. A certain superstructure in 2020 is the liberalization of the mortgage market. In 2009, this loosening was not possible because the mortgage market was not very regulated. Given the origin of the crisis, this would not even be appropriate.

Comparing fiscal policy measures is relatively more complex. We have the final account for 2009, but not the final account for 2020. In 2009, the measures were milder. It was more about reducing payments, tax reforms, etc. In 2020, state support was much more massive. Perhaps because the cause of the shutdown of the economy was the state, not insufficient foreign demand. This year, the state reached much higher direct subsidies, which fall into the category of so-called transfer payments. He offered much higher guarantees, forgave advances on health and social insurance to self-employed persons. He even tried to intervene in the banking sector. He also approached pension policy, although only in the segment of protective medical devices. We can therefore state that in 2020 , support for the domestic economy was much more vigorous and a wider constellation of fiscal policy instruments was used. However, we cannot forget that part of these government expenditures could have been connected not only with the economic cycle, but especially with the political cycle, because in the autumn regional elections will be held in the Czech Republic, from which new governors and regional councils will emerge.

The main difference, however, is that in 2009 the supply side of the economy was primarily supported. In 2020, the government also significantly supported the demand side. The fiscal package in 2009 was published in one comprehensive document. In 2020, fiscal policy measures were issued gradually, according to the current situation. They lack continuity, thoughtfulness, they lack concept.

\section{References}

1. Dixon, H., Luintel, K., Tian, K. (2020). The impact of the 2008 crisis on UK prices: What we can learn fromthe CPI microdata. Oxford Bulletin of Economics and Statistics. Early access.

2. Jetter, M., Magnusson, L.M., Roth, S. (2020). Becoming sensitive: Males' risk and time preferences after the 2008 financial crisis. European Economic Review, 128, 103512.

3. Song, W.L., Wang, H. (2020). Do institutional investors know banks better? Evidence from institutional trading surrounding the 2008 financial crisis. Journal of Accounting, Auditing and Finance, 35(4), 777-802. 
4. Váchal, A., Krejčíř, J., Poláček, D., Neufus, O., Nevyhoštěný, J., Kunc, T. (2018, September 7). Před 10 lety přišel obři otřes. Globální ekonomická krize v čislech a datech. Aktualne.cz. https://zpravy.aktualne.cz/ekonomika/globalni-ekonomicka-krize2008-v-datech-den-po-dni/r $\sim 5 f 4503 a c b 10111$ e899900cc47ab5f122/

5. ČNB. (2008, February 2). Prognóza ČNB z února 2008. Česká národní banka. https://www.cnb.cz/cs/menova-politika/prognoza/prognoza-cnb-archiv/PrognozaCNB-z-unora-2008/

6. ČSUU. (2011, January). Dopady světové finanční a hospodářské krize na ekonomiku ČR. Český statistický úrad.

https://www.czso.cz/documents/10180/20534938/115610j.pdf/b487dd3c-0ad7-4ccdb62d-8fc9bf917b95?version $=1.0$

7. ČNB. (2020, September 11). Vybrané devizové kurzy. Česká národní banka. https://www.cnb.cz/cs/financni-trhy/devizovy-trh/kurzy-devizoveho-trhu/kurzydevizoveho-trhu/grafy_form.html

8. Vláda ČR. (2009, February 18). Národní protikrizový plán. Vláda ČR. https://www.vlada.cz/assets/media-centrum/predstavujeme/narodni-protikrizovyplan.pdf

9. ČNNB. (2020, March 27). Jak se vyvíjela diskontní sazba ČNB? Česká národní banka. https://www.cnb.cz/cs/casto-kladene-dotazy/Jak-se-vyvijela-diskontni-sazba-CNB/

10. Shi, Q., Dorling, D., Cao, G., Liu, T. (2020). Changes in population movement make COVID-19 spread differently from SARS. Social Science \&Medicine, 225, 113036.

11. Binder, C. (2020). Coronavirus fears and macroeconomic expectations. Review of Economic and Statistics, 102(4), 721-730.

12. Mitha, S. (2020). UK COVID-19 diary: Policy and impacts. National Tax Journal, 73(3), 847-878.

13. Jung, J., Lee, H., Song, K. (2020). Public finance responses to covid-19 in Korea. National Tax Journal, 73(3), 879-899.

14. Murray, J. (2020). COVID-19: SWEDISH STRATEGY Has Sweden's controversial covid-19 strategy been successful or not? British Medical Journal, 370, m3255.

15. Dani, M., Menendez, A.J. (2020). The first EU measures in response to the economic consequences of the covid-19 crisis. Biolaw Journal - Rivista Di Biodiritto, 1(SI), 527539.

16. ČSÚ. (2020, November 3). Zaměstnanost, nezaměstnanost - časové řady. Český statistický úřad. https://www.czso.cz/csu/czso/zam_cr

17. ČSÚ. (2020, October 1). Hlavní makroekonomické ukazatele. Český statistický úřad. https://www.czso.cz/csu/czso/hmu_cr

18. Singh, G., Dharampal, J. (2020). Economic impact od covid-19 pamdemic: Who are the big sufferers? Indian Journal of Economics and Devlopment, 16(2), 320-326.

19. Vláda ČR. (2020, September 10). Podpora a úlevy pro podnikatele a zaměstnance. Vláda ČR. https://www.vlada.cz/cz/epidemie-koronaviru/dulezite-informace/podporaa-ulevy-pro-podnikatele-a-zamestnance-180601/

20. Placek, M., Spacek, D., Ochrana, F. (2020). Public leadership and strategies of Czech municipalities during the COVID-19 pandemic - municipal activism vs municipal passivism. International Journal of Public Leadership, Early access.

21. Dingel, J.I., Neiman, B. (2020). How many jobs can be done at home? Journal of Public economics, 189(SI). 
22. Syrovátka, J. (2020, August 13). Opatření ČNB v reakci na nákazu covid-19. Česká národní banka. https://www.cnb.cz/cs/menova-politika/zpravy-o-inflaci/tematickeprilohy-a-boxy/Opatreni-CNB-v-reakci-na-nakazu-covid-19/ 